BANCA D'ITALIA

E U ROS I S T E M A

Temi di discussione

(Working Papers)

Foreclosures and house prices

by Michele Loberto 

$\mathbb{B}^{-3}$ BANCA D'ITALIA

E U ROS IS T E MA

\section{Temi di discussione}

(Working Papers)

Foreclosures and house prices

by Michele Loberto

Number 1325 - March 2021 
The papers published in the Temi di discussione series describe preliminary results and are made available to the public to encourage discussion and elicit comments.

The views expressed in the articles are those of the authors and do not involve the responsibility of the Bank.

Editorial Board: Federico Cingano, Marianna Riggi, Monica Andini, Audinga Baltrunaite, Marco Bottone, Davide Delle Monache, Sara Formai, Francesco Franceschi, Adriana Grasso, Salvatore lo Bello, Juho Taneli Makinen, Luca Metelli, Marco Savegnago.

Editorial Assistants: Alessandra Giammarco, Roberto Marano.

ISSN 1594-7939 (print)

ISSN 2281-3950 (online)

Printed by the Printing and Publishing Division of the Bank of Italy 


\title{
FORECLOSURES AND HOUSE PRICES
}

\author{
by Michele Loberto*
}

\begin{abstract}
This paper studies the impact of foreclosures on house prices in Italy using a large dataset of listings. We estimate that the foreclosure discount is considerable, and this would suggest a high degree of market segmentation and limited spillovers from foreclosures to the market for non-foreclosed homes. However, we find that the entry of foreclosures into the market increases the propensity of home sellers to adjust their list price. Moreover, foreclosure listings have a significant and negative impact on the prices of non-foreclosed homes nearby. Our evidence is quantitatively consistent with the recent literature on the impact of foreclosures on the US housing market.
\end{abstract}

JEL Classification: R31.

Keywords: house prices, foreclosures, neighborhood effects.

DOI: $10.32057 / 0 . T D .2021 .1325$

\section{Contents}

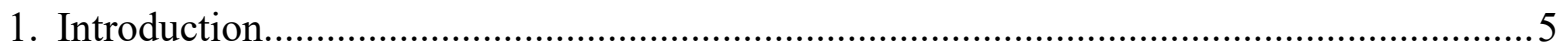

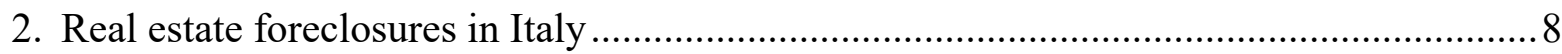

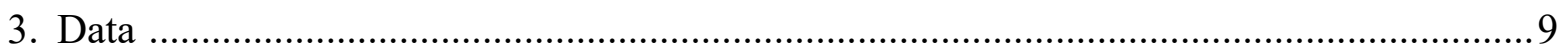

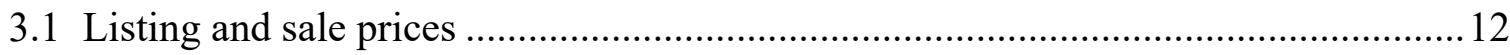

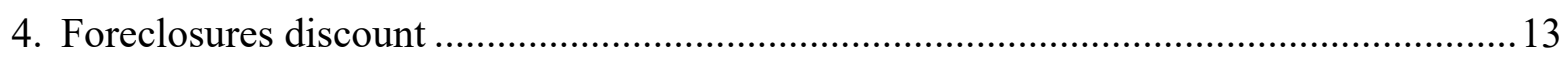

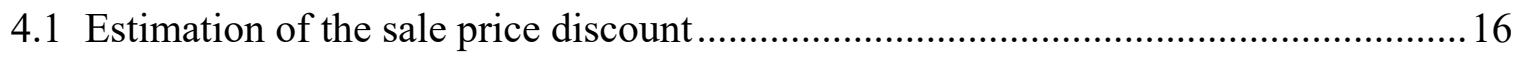

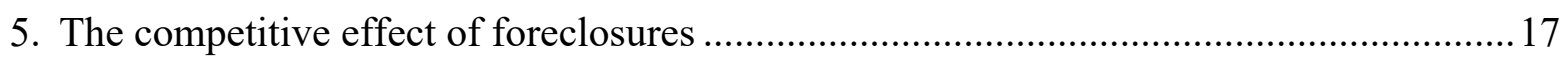

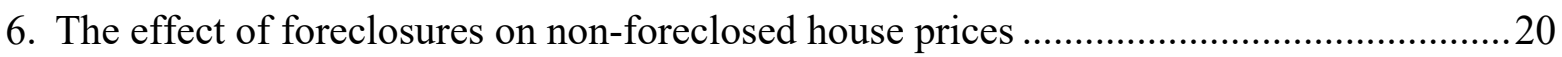

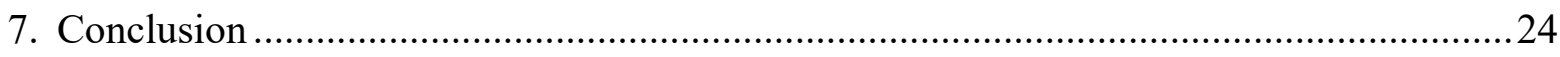

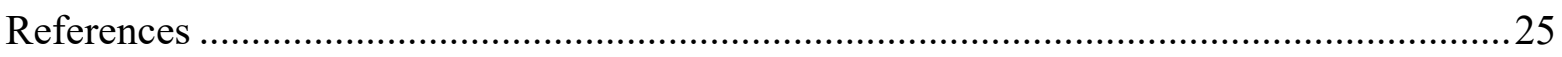

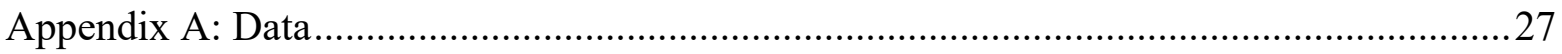

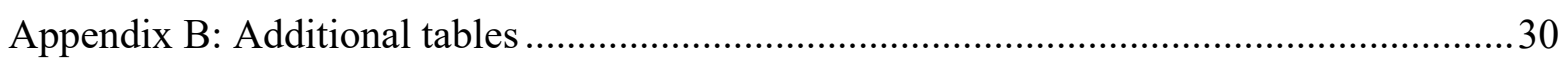

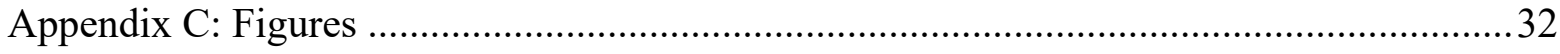

* Bank of Italy, Directorate General for Economics, Statistics and Research. 



\section{Introduction $^{1}$}

During the period 2008-13, the Italian economy suffered a severe double-dip recession. One of the consequences of the decline in economic activity was the sharp rise in default rates, particularly in the real estate sector. Default rates were high among construction and real estate firms, and they reached their historical peak also for households (Ciocchetta et al., 2016).

Therefore, a large number of real estate properties have been foreclosed to repay the debts incurred by the debtors. In the three years 2016-2018, the average annual number of pending foreclosures procedures - the process that lenders must follow to recover amounts still due - was about 250,000 , many of them involving dwellings. Since the stock of foreclosures has been vast compared to the trading volumes in the market, it is relevant to investigate whether and how foreclosures affected the real estate market. ${ }^{2}$ This question is also timely, as the economic recession caused by the COVID-19 epidemic is likely to lead to a new wave of mortgage defaults and foreclosures.

In this paper, in particular, we focus on the impact of foreclosures on housing prices in Italy. Although no specific analysis has been carried out so far on this issue for the Italian case, the conventional wisdom was that foreclosures spillovers would have been null or very limited. This belief was motivated by the fact that the purchase of foreclosed houses - that occurs through auctions managed by the courts - was for many reasons very complicated. ${ }^{3}$ However, this situation could have changed since 2015, when legislative reforms aimed to simplify the process of selling foreclosed properties entered into force.

Based on our knowledge, the impact of foreclosures on house prices has been studied only for the US. This paper is the first to examine the spillovers of foreclosures on the housing market in a country with relevant institutional differences compared to the US. We believe that this is important to understand better to which extent and how foreclosures affect the housing market. The Italian case is quite interesting for two reasons. First, mortgage loans to households are recourse, and this softens the feedback effect from house prices on foreclosures. ${ }^{4}$ Second, the inefficiencies in the foreclosure process give rise to a considerable foreclosure price discount (i.e. the percentage

\footnotetext{
${ }^{1}$ I'm extremely grateful to Immobiliare.it for providing the data and for their assistance. The underlying data have been provided free of charge by Immobiliare.it for research purposes. They contain no personal confidential information. I thank Andrea Nobili, Tommaso Orlando, Stefano Neri and Roberta Zizza for their comments, and Andrea Luciani for his assistance. All errors are my own.

${ }^{2}$ During the period 2016-2018, the average annual number of property sales was about 1.1 million.

${ }^{3}$ For example, until 2015, the buyer of a foreclosed home had to pay the price offered in a single installment, and he could not take out a mortgage for the purchase.

${ }^{4}$ Following the borrower's insolvency, when the loan is recourse, the lender can go after all the borrower's assets until he gets a full repayment of the loan.
} 
difference between the price of a foreclosed home and the market price of the same house if sold in an unforced transaction), which is far higher compared to the estimates available for the US. Because of this considerable foreclosure price discount, one could expect a very limited arbitrage between the market for foreclosed homes and the market for non-foreclosed properties.

First, we estimate the foreclosure discount. Second, we analyze if the price-setting strategies of home sellers are affected by the competition of nearby foreclosure listings. Finally, we estimate the spillovers of foreclosures on the prices of non-foreclosed nearby houses. Surprisingly, our results are very similar to some of the most reliable estimates for the US, although the institutional framework is very different between Italy and the US.

We analyze a large dataset of listings published on Immobiliare.it - the largest online website for real estate services in Italy - between the second half of 2016 and December 2018. Our data cover about one hundred main cities, representing nearly one-third of the Italian population and house sales. Overall, we observe the listing history of about 750 thousand dwellings at a weekly frequency. For each home, we know the timing of entry into the market and delisting (i.e. when the property exits from the market), a large set of physical characteristics, the time series of the asking prices, and the timing of price revisions.

We estimate that the foreclosure discount is approximately between 42 and 56 percent. The discount is heterogeneous across cities and varies with the characteristics and the geographical position of the property. It is higher for smaller dwellings and those in suburban neighborhoods.

Such a high discount would suggest that the market for foreclosures is isolated from other segments of the housing market. Strong segmentation would imply limited spillovers from foreclosures to the housing market. However, this is not the case. Following the approach proposed by Anenberg and Kung (2014), we find that home sellers have a higher propensity to revise downward their asking price in the same week and the week following the market entry of a nearby foreclosed house. That is consistent with the hypothesis that home sellers consider foreclosed houses as competitors, and because of the considerable foreclosure discount, they react by lowering their price.

The exact timing of the market entry of a foreclosed home is not correlated with some unobservables that simultaneously affect the likelihood of price revisions. It is the output of an administrative process. Therefore, we can say that the listing of a foreclosed home causes a reaction from nearby home sellers. We show that this effect is local. It is statistically significant and economically relevant up to a distance of 150 meters from the foreclosed house. ${ }^{5}$ Then it decreases

\footnotetext{
${ }^{5}$ The probability of changing the list price increases by 0.3 percent following the market entry of a foreclosure. This effect is sizeable because home sellers do not frequently adjust their asking price in Italy. The average probability of changing the list price is 1.4 percent.
} 
and becomes very small at 400 meters.

Foreclosures compete in the housing market with non-foreclosure listings. Consequently, it is essential to investigate to what extent foreclosures influence the prices of nearby non-foreclosed properties. Estimating the causal effect of foreclosures on house prices is complicated because they are strongly interrelated. Foreclosures are endogenous to house prices because a fall in house prices reduce the equity value of dwellings. If the value of a house falls below that of the outstanding mortgage debt taken to buy it (negative equity) the homeowner has the incentive to default on his debt strategically. ${ }^{6}$

Moreover, there can be common shocks that may affect both house prices and foreclosures. A typical example is an income shock resulting from the shutdown of some relevant economic activity within a neighborhood. Some debtors may lose their jobs and no longer be able to pay their debts. Their homes would be foreclosed and sold through judicial auctions. At the same time, a lower income in the neighborhood would lead to lower demand for housing and lower house prices.

We follow an approach similar to Campbell et al. (2011) and Anenberg and Kung (2014). We find that the impact of foreclosures on nearby house listing prices is negative and significant. The final listing price of dwellings distant less than 150 meters from a foreclosed home is lower by 1.1 percent, an estimate very similar to those of Campbell et al. (2011) and Anenberg and Kung (2014) for the US. We believe that estimate is a good approximation for the impact on sale prices because listing and sale prices have had a very similar trend during 2016-2018. Moreover, we do not find evidence that foreclosures affect the average discount over asking prices that buyers obtain from sellers.

The most related paper is Anenberg and Kung (2014). As in their case, we take advantage of the high frequency of listing data to identify causal relationships. The strategy to estimate the impact of foreclosures on house prices is similar to Campbell et al. (2011). We discuss in section 6 the difference between our specification and their econometric strategy. Other recent studies on foreclosure spillovers are Immergluck and Smith (2006), Harding et al. (2009), Hartley (2014), Mian et al. (2015) and Gerardi et al. (2015). All these papers study the effects of foreclosures based on US data, and almost all of them have limited geographical coverage. On the opposite, this paper studies foreclosure spillovers in Italy, a country with a very different institutional framework from the US concerning foreclosures and the housing market, and covers all the main cities. Cohen et al. (2016) provide a rich overview of this literature, and they show that the spillover effects of nearby foreclosed properties are generally less than 2 percent.

Section 2 describes the institutional framework for foreclosures in Italy and recent developments

\footnotetext{
${ }^{6}$ This issue is in Italy less relevant than in the US because mortgage loans to households are recourse.
} 
in the foreclosures market. Section 3 describes the data used in the paper. In Section 4 we estimate the foreclosure discount. In section 5 , we demonstrate that the presence of nearby foreclosed houses affects the propensity of home sellers to revise their prices downwards. In section 6 , we estimate the effect of the presence of an auction house on non-auction houses. Finally, section 7 concludes.

\section{Real estate foreclosures in Italy}

Following the default of a debtor, the sale of real estate assets used as collateral takes place through a judicial foreclosure. The lender must go through a court to get permission to foreclose by proving the borrower is delinquent. If the court confirms that the debt is in default, it sets an auction for the sale of the foreclosed property to acquire funds to repay the lender.

The court entrusts the sale of the house to a delegate. The latter is responsible for advertising and organizing the house sale. The auction takes place on a predetermined day, and the listing period must be at least 45 days. The initial price for the house is its market value estimated by real estate appraiser chosen by the court. If no one has bid on the house, the court will reduce the reference price by at most 25 percent and organize a new auction, guaranteeing a sufficiently long listing period at each time. ${ }^{7}$ Usually, a foreclosed house is sold after multiple rounds. Considering foreclosures closed in 2017, Giacomelli et al. (2019) show that the average number of auctions was 2.3 .

According to Astasy - a private company offering brokerage and advisory services in the context of foreclosure procedures - about 165 thousand housing units have been posted on sale through judicial auctions during 2017. Although no exact figures are available to us, foreclosures are by far the main determinant of judicial auctions of housing units. ${ }^{8}$

The regulatory framework for real estate foreclosures has undergone significant changes in the years 2015-2016. One of the main objectives of these reforms has been to speed up the sale of the house. For our purposes, the 2015 reform has been the most important, as it reduced the segmentation between the house property market and the one for foreclosed dwellings drastically. ${ }^{9}$

\footnotetext{
${ }^{7}$ Following three unsuccessful auctions, the reduction in the reference price can be up to 50 percent.

${ }^{8}$ According to Astasy, 78 percent of the judicial sales that took place in 2017 were related to foreclosures, while the remainder were associated with companies bankruptcy proceedings. Since companies in Italy hold only about 7 percent of the housing stock, it is reasonable to assume that judicial auctions are associated with foreclosures.

${ }^{9}$ The main innovation of the subsequent 2016 reform was the introduction of the power of law clause (Patto Marciano). The new law makes it possible to include in the mortgage loan agreements a specific provision that allows the bank the right to obtain ownership of the house through an out-of-court proceeding following the default of the debtor. According to Bank of Italy (2018), this clause has not been used by Italian banks until 2018. Moreover, since it would apply only to new contracts, it is implausible that foreclosures following this alternative procedure already
} 
First of all, before this reform houses were sold through minimum bid auction, meaning that the court could accept bids at or above the disclosed price. In the new framework, if the court assesses that there is no prospect to get a better price through a new auction, bids can instead be accepted even if they are 25 percent lower than the reference price.

Moreover, it is now possible for the winning bidder to pay the price in installments, whereas before a lump sum payment for the entire amount was required. Further, the buyer can now get immediate possession of the property, provided it receives a guarantee from banks or by insurance firms. Finally, it is now possible to take out a mortgage loan to buy a foreclosed dwelling.

Overall, since 2016 the greater ease for potential buyers to buy a foreclosed house at auction at a price well below market value has plausibly made this market competitive with the other segments of the housing market. ${ }^{10}$

\section{Data}

We analyze a dataset of house listings provided by Immobiliare.it, the largest online portal for real estate services in Italy. The dataset covers the whole country. Because there are representativeness issues in small towns and villages, we only consider the listings in 109 cities that are the capitals of the NUTS 3 Italian regions. ${ }^{11}$ The total population in these cities is about 18 million inhabitants, and one-third of the total housing sales in Italy takes place in these cities.

We use weekly snapshots of all the ads visible on their website every Monday, from 2016, July 4 until 2018, December 31. For each advertisement, we have access to a rich information set. We have detailed information about the physical characteristics and the location of the dwelling (see Appendix A for the complete list of variables). We keep track of all the variations concerning the asking prices and the related timing of price changes. For judicial auctions, we observe the reference price set by the court. We also know in which day the ad was created and the day when it was removed. Unfortunately, we do not know if a delisting follows a sale or withdrawn from the market, and we do not observe the transaction prices.

As already stressed by Anenberg and Kung (2014), listings data provide several advantages compared to transaction prices. First, using high-frequency data with the observation of which dwellings are listed at each time is crucial in identifying causal relationships between foreclosures occurred.

${ }^{10}$ For a more exhaustive description of the regulatory framework see Giacomelli et al. (2019) and the references therein.

${ }^{11}$ Nomenclature of Territorial Units for Statistics (NUTS) is the geocode standard used in Europe for referencing the subdivisions of countries for statistical purposes. 
and the housing market. Second, there are many more list prices at any given time in any given geography than sale prices. Combined with the rich information set about the house characteristics, listings allow a more accurate estimation of the house prices dynamics at a very granular level.

Online listings can include several ads referring to the same dwelling. The owner of a house can entrust several real estate agencies for the sale of her home, and each of these agencies could publish a different ad. We employ the methodology described in Loberto et al. (2020) to get rid of duplicated ads through machine learning techniques and make online listings representative of the Italian housing market. Loosely speaking, we employ a classification tree to decide if different ads refer to the same dwelling based on geolocation, asking prices and dwellings characteristics.

Table 1: Descriptive statistics

\begin{tabular}{|c|c|c|c|c|c|c|}
\hline & $\mathrm{N}$ & Price & Price per s.m. & Surface & $\begin{array}{l}\text { Share of the } \\
\text { housing stock }\end{array}$ & $\begin{array}{l}\text { Share of } \\
\text { the supply }\end{array}$ \\
\hline & \multicolumn{6}{|c|}{ Full sample } \\
\hline Foreclosures & 33,702 & 129,777 & $1,200.5$ & 101.8 & 0.04 & 2.95 \\
\hline \multirow[t]{2}{*}{ Other listings } & 590,220 & 270,815 & $2,521.2$ & 112.6 & 1.41 & \\
\hline & \multicolumn{6}{|c|}{ Years } \\
\hline \multicolumn{7}{|l|}{2016} \\
\hline Foreclosures & 9,866 & 137,889 & 1,301.6 & 99.8 & 0.04 & 3.10 \\
\hline Other listings & 214,684 & 274,701 & $2,599.6$ & 112.1 & 1.40 & \\
\hline \multicolumn{7}{|l|}{2017} \\
\hline Foreclosures & 16,612 & 121,732 & $1,153.2$ & 99.4 & 0.05 & 3.28 \\
\hline Other listings & 309,151 & 271,651 & $2,529.2$ & 112.6 & 1.38 & \\
\hline \multicolumn{7}{|l|}{2018} \\
\hline Foreclosures & 14,804 & 133,692 & $1,198.3$ & 105.1 & 0.04 & 2.56 \\
\hline \multirow[t]{2}{*}{ Other listings } & 315,904 & 268,177 & $2,476.4$ & 112.9 & 1.43 & \\
\hline & \multicolumn{6}{|c|}{ Cities } \\
\hline \multicolumn{7}{|l|}{ Turin } \\
\hline Foreclosures & 4,711 & 66,797 & 800.8 & 76.0 & 0.10 & 5.28 \\
\hline Other listings & 42,482 & 187,277 & $1,906.2$ & 95.2 & 1.73 & \\
\hline \multicolumn{7}{|l|}{ Milan } \\
\hline Foreclosures & 7,005 & 104,548 & $1,281.0$ & 70.9 & 0.09 & 4.83 \\
\hline Other listings & 58,173 & 407,796 & $3,914.3$ & 106.2 & 1.69 & \\
\hline \multicolumn{7}{|l|}{ Rome } \\
\hline Foreclosures & 7,305 & 197,351 & $1,650.7$ & 118.7 & 0.08 & 3.97 \\
\hline Other listings & 117,365 & 378,770 & $3,624.5$ & 110.8 & 2.01 & \\
\hline
\end{tabular}

Note: Prices are measured in euro. Shares are reported in percentage points. We measure the share of listings over the housing stock as the average daily number of listings divided by the number of all dwellings. Supply is defined as the average daily number of all listings. The column "Share of the supply" reports the average daily number of foreclosures listings (non-foreclosures listings) over all listings. In the first column the sum of the number of listings in different years is greater than the total because many dwellings are listed during two or more years. Data for 2016 starts from July. 
The dataset counts 623,922 dwellings. Of these, 33,702 houses are sold through judicial auctions, while the remaining 590,220 dwellings are standard listings, i.e. they are not related to a foreclosure procedure (Table 1). Foreclosed homes are smaller than other listings, and they are much cheaper. On average, foreclosed homes are large 101.8 square meters, and the reference price set by the court is 129,777 euros; the average size of other listings is 112.6 square meters, and the average price asked by the seller is 270,815 euros. The average price per square meter of foreclosed homes is 1,200.5 euros, which is only 47.6 percent of the average asking price of other listings.

Foreclosures are a small fraction of listings. On a given day, they account for about 3 percent of all listings, and their share over total housing stock is 0.04 percent.

These findings are qualitatively similar over time. On the opposite, we find more heterogeneity between different cities. Table 1 reports the statistics for the three biggest housing markets, namely Rome, Milan, and Turin. Compared to the full sample, in these cities foreclosed homes account for a higher share of total listings (between 4 and 5.3 percent). The average reference price per square meter of foreclosed homes is much lower than the average asking price of other listings. In Milan, the average reference price of a foreclosed home is only 32 percent of the average asking price. Finally, foreclosed homes are much smaller than other listings in Milan and Turin, while the opposite happens in Rome.

The geographical distribution of foreclosed homes differs from other listings. The correlation at the local housing market level ${ }^{12}$ between the stock of dwellings and the number of foreclosure listings over the full period is relatively low compared to the correlation with non-foreclosures listings $(0.58$ and 0.91, respectively; see Table B.2 in Appendix B). Foreclosures are more concentrated in the suburbs, while other listings have a distribution similar to the one of the housing stock (see Figure C.1 in Appendix C). Besides, a foreclosed home is likely to be in a worse state of conservation than other houses because an owner that is experiencing difficulties in repaying the debt hardly devoted resources to maintenance.

We divide the territory of each city into local housing markets using the partition developed by OMI, a branch of the Italian Tax Office. The OMI microzones are contiguous areas of the city territory that satisfy strict requirements in terms of homogeneity of house prices, urban characteristics, socioeconomic characteristics, and the endowment of services and urban infrastructures. Unlike the census tracts, the OMI microzones are local homogeneous housing markets. ${ }^{13}$

The average number of households in an OMI microzone is 3,528 units, and the average housing stock is 4,166 units. The average share of owner-occupied households is 68.3 percent. The

\footnotetext{
${ }^{12}$ We explain below our definition of the local housing market.

${ }^{13} \mathrm{OMI}$ microzones are periodically revised to satisfy these criteria and to better approximate local housing markets. The last revision dates back to 2014 .
} 
microzones have quite different sizes because they aim to approximate local housing markets. Table B.1 in Appendix B reports the quantiles of the distributions of these variables and additional information about average house values and asking prices.

\subsection{Listing and sale prices}

As we do not have access to administrative data on house sales, we observe only the listing prices. In general, this is a significant limitation, but it seems to be a less problematic issue in our case. In Figure C.2 we show that the average listing and sale prices in the cities of our sample have had a very similar evolution during the reference period we are considering. ${ }^{14}$ Listing prices declined slightly more than sale prices because of the simultaneous reduction in the average discount obtained by buyers.

We are not claiming that considering listing prices is the same as observing sales prices. However, in the period covered by our analysis, it seems that listing prices are a good proxy for sale prices, and foreclosures are unrelated to the wedge between average listing and sale prices.

To confirm these hypotheses, we estimated the average discount on listing prices for all local housing markets, based on listing prices and OMI data. ${ }^{15}$ In Italy, only a minimal share of transactions end up with a sale price equal or higher than the listing price, and there is no evidence that owners set low asking prices to trigger an auction among potential buyers. ${ }^{16}$ In Figure C.3, we show that both the median and the weighted (by the housing stock) average of the distribution of the discounts in the different microzones trend downward, albeit slightly. Considering the median of this distribution, the discount has been between 12 and 13 percent for the period 2017-2018 and somewhat higher in the second half of 2016. This estimate is consistent with the Italian Housing Market Survey results, although the estimates of this survey refer to the whole country, not just to the cities in our sample (Figure C.3). In the following, we refer to the median as the best estimate for the discount, and during our reference period, it was 12.7 percent on average.

Notice that in some cities the discount has been virtually stable. For example, in the two main Italian cities (Rome and Milan), the evolution of listing and sale prices in our reference period was almost the same (see Figure C.2).

Although on average listing and sale prices have had the same evolution, there is still some concern that foreclosed homes may affect the average discount on the listing prices of non-foreclosed

\footnotetext{
${ }^{14}$ See Appendix A for the details about sale prices.

${ }^{15}$ See Appendix 3 for a description of the methodology that we used to estimate the discount.

${ }^{16}$ According to the Italian Housing Market Survey, in our reference period, that share was about 5 percent. In general, brokers do not accept further offers if the seller is already negotiating with a potential buyer, ruling out auctions for the same house.
} 
homes. If this is the case, we should be able to find evidence of this relationship at the local market level. We test for the presence of such a relationship using the following OLS model:

$$
r_{j k t}=\alpha_{k}+\gamma_{t}+\beta_{F} N_{j t}^{F}+\beta_{O} N_{j t}^{O}+\delta \mathbf{X}_{j}+\varepsilon_{j k t}
$$

where $r_{j k t}$ is the ratio between the average listing and sale prices for non-foreclosed properties in microzone $j$, belonging to city $k$ during the semester $t . N_{j t}^{F}$ and $N_{j t}^{O}$ are the number of foreclosed and non-foreclosed properties, respectively, listed during period $t$ in the microzone $j . \alpha_{k}$ and $\gamma_{t}$ are city and time dummies, respectively. $\mathbf{X}_{j}$ is a vector of microzone characteristics, namely the number of dwellings according to the 2011 Census and the location inside the city (central, semi-central, suburbs).

The results of this regression are reported in Table B.3 in Appendix B. The coefficient for $N_{j t}^{F}$ is not statistically significant, differently from the parameter $N_{j t}^{O}$. We find no correlation between the number of foreclosure listings and the average discount. On the opposite, a larger number of non-foreclosure listings increases the bargaining power of buyers and implies a larger wedge between listing and sale prices.

As a further argument to support the hypothesis that foreclosures do not affect the average discount on listing prices, in section 6 we will show that there is no causal effect of foreclosures on the time-on-market in Italy. That is important because the correlation between time-on-market and average discount on asking prices is high. Therefore, it seems implausible that foreclosures affect the average discount but not the time-on-market. The positive correlation between the average discount and the time-on-market holds both at aggregate level (Figure C.3) and local housing market level (Table B.3). ${ }^{17}$

\section{Foreclosures discount}

According to the evidence of the previous section, foreclosed homes are sold at a price far lower than market values, in line with the results in the literature. On average, the reference prices of foreclosed houses are 52.4 percentage points lower than the asking prices of other listings, partly because these houses may show up systematically different characteristics than those of other listings.

However, the literature has shown that foreclosed homes are traded at a lower price than market price even when different physical and location characteristics are taken into account. In this

\footnotetext{
${ }^{17}$ In Table B.3, we report the results of the regression of the average ratio between listing and sale prices for non-foreclosed properties during the reference period and the average time-on-market. We control for city effects and the microzone characteristics considered in (1). As expected, a longer time-on-market is associated with a larger wedge between listing and sale prices.
} 
section, we want to estimate the percentage difference between the price of a foreclosed home and the price of houses sold in an unforced transaction, the so-called foreclosure discount. Unfortunately, we do not observe the sale prices. Then, we compare the last reference price established by the court to the listing prices for non-foreclosed properties. The estimate provides a useful reference to identify the interval in which the discount on sale prices lies.

Following the methodology proposed in Campbell et al. (2011), we estimate the following regression model:

$$
P_{i j t}=\alpha_{j t}+\beta \mathbf{X}_{i}+\xi F_{i}+\varepsilon_{i j t}
$$

where $P_{i j t}$ is the logarithm of the last observed reference/asking price for dwelling $i$, located in the microzone $j$ and delisted in quarter $t$. We control for house price variation over time at the microzone level by including the the terms $\alpha_{j t} . \mathbf{X}_{i}$ is the vector of physical characteristics of houses $i$, and includes the property type (apartment or detached house), size (square meters), number of bathrooms, presence of a balcony, parking space/box, maintenance status and floor level. Finally $F_{i}$ is a indicator variable that identifies if house $i$ is sold through a judicial auction.

We also extend the baseline equation (2) to include an interaction term of $F_{i}$ with other house characteristics. In particular, we test if the discount varies with the size, price, and geographical position of the house inside the city. We also test if the discount depends on the tightness of the housing market at the city level, including the interaction term of $F_{i}$ with the year-on-year growth rate of house prices in the city.

Table 2 reports the estimates for the four different specifications. In the baseline regression (column 1), the estimate of $\xi$ is significant and equal to -0.653 . That implies a price discount equal to $1-e^{-0.653}=48.0$ percent. ${ }^{18}$ Columns 2 and 3 show that the foreclosure discount decreases with the size and the price of the house.

In column 4, we test if the discount is affected by the tightness of the housing market, using as a proxy of market tightness the year-on-year growth rate of asking prices of non-foreclosure listings. We compute these growth rates at the city level, instead of at the microzone level, to avoid potential spillovers from foreclosed properties to the asking prices of the other listings. The hypothesis is that the foreclosure discount is lower in cities the housing market is performing better. However, we find that the interaction term is statistically significant but very small. Then, there is no relevant systematic difference in the foreclosure discount between cities where prices are increasing and those where they are falling.

\footnotetext{
${ }^{18}$ Kennedy (1981) shows that the OLS estimate of $\xi$ in (2) is biased, and the distortion can be corrected by taking into account the square of the standard error of the estimated parameter. Since the standard error is very small (0.003), this correction would not change the estimated foreclosure discount.
} 
Table 2: Foreclosure discount

\begin{tabular}{|c|c|c|c|c|c|}
\hline & \multicolumn{5}{|c|}{ Listing price } \\
\hline & (1) & $(2)$ & (3) & (4) & (5) \\
\hline Foreclosure & $\begin{array}{c}-0.653^{* * *} \\
(0.003)\end{array}$ & $\begin{array}{c}-0.811^{* * *} \\
(0.005)\end{array}$ & $\begin{array}{c}-0.857^{* * *} \\
(0.004)\end{array}$ & $\begin{array}{c}-0.667^{* * *} \\
(0.004)\end{array}$ & $\begin{array}{c}-0.486^{* * *} \\
(0.010)\end{array}$ \\
\hline Foreclosure $\times$ Floor area & & $\begin{array}{c}0.002^{* * *} \\
(0.000)\end{array}$ & & & \\
\hline Foreclosure $\times$ Price & & & $\begin{array}{c}0.000^{* * *} \\
(0.000)\end{array}$ & & \\
\hline Foreclosure $\times$ Market tightness & & & & $\begin{array}{c}-0.008^{* * *} \\
(0.001)\end{array}$ & \\
\hline Foreclosure $\times$ Location: semi-central & & & & & $\begin{array}{c}-0.111^{* * *} \\
(0.012)\end{array}$ \\
\hline Foreclosure $\times$ Location: suburbs & & & & & $\begin{array}{c}-0.233^{* * *} \\
(0.011)\end{array}$ \\
\hline Foreclosure $\times$ Location: out-of-town & & & & & $\begin{array}{c}-0.185^{* * *} \\
(0.030)\end{array}$ \\
\hline Dummies & $\begin{array}{l}\text { Microzone } \\
\text {-quarter }\end{array}$ & $\begin{array}{l}\text { Microzone } \\
\text {-quarter }\end{array}$ & $\begin{array}{l}\text { Microzone } \\
\text {-quarter }\end{array}$ & $\begin{array}{l}\text { Microzone } \\
\text {-quarter }\end{array}$ & $\begin{array}{c}\text { Microzone } \\
\text {-quarter }\end{array}$ \\
\hline Observations & 550,219 & 550,219 & 550,219 & 543,816 & 543,984 \\
\hline Adjusted $\mathrm{R}^{2}$ & 0.536 & 0.537 & 0.542 & 0.527 & 0.536 \\
\hline
\end{tabular}

Notes: The dependent variable is the log of the last observed asking price before delisting. We control for the following home physical characteristics: property type (apartment or detached house), size (square meters), number of bathrooms, presence of a balcony, parking space/box, maintenance status and floor level. Time effects refer to the quarter in which a house is delisted. ${ }^{* * *}$ Significant at the 1 percent level. ${ }^{* *}$ Significant at the 5 percent level. *Significant at the 10 percent level. 
Finally, column 5 reports that the magnitude of the price discount is strongly affected by the geographical position inside the city. For houses in the city center, the price discount is roughly 38 percent, and increases moving outward. The price discount of foreclosed homes in suburbs is higher than 50 percent.

\subsection{Estimation of the sale price discount}

As we have already said, we do not observe sale prices. For foreclosed houses, we know the reference price set by the court. For the other homes, we observe the asking prices posted by the sellers. In this section, we use our estimates based on listing prices, and additional data sources, to estimate the percentage difference between the sale price of a foreclosed home and the sale price of houses sold in unforced transactions. Although we cannot provide a point estimate of the foreclosure sale price discount, we can identify a reasonable interval for this parameter.

Regarding the sale price of foreclosed homes, the institutional details of judicial auctions allow us to make reasonable assumptions about the interval in which the final price for foreclosed properties is. The court sets the reference price, starting from the estimated market value of the house. If there are no bids, the court decreases the reference price by at most 25 percent and calls for new bids. That goes on iteratively as long as no bid is made. Since the minimum bid in each round can be computed by discounting the reference price set by the court by 25 percent, the last reference price is plausibly an upper bound for the sale price of the foreclosed home, while the minimum offer is a lower bound.

Then, we also use our preferred estimate of the average discount applied to the asking prices, which is 12.7 percent (see section 3.1), to discount listing prices.

Under these assumptions, the average foreclosure discount to sale prices is approximately between 42 and 56 percent, ${ }^{19}$ a range that is consistent with the estimates of market operators. ${ }^{20}$ These figures are much higher compared to the evidence for the US. ${ }^{21}$ A possible explanation for this result is that the market for foreclosed homes is isolated from the other segments of the hous-

\footnotetext{
${ }^{19}$ We obtain the lower bound of the interval by multiplying the estimate of the previous section, 48.0 percent, by $1-0.127=0.873$ to keep into account the discount on asking prices. For the lower bound, we assume that the sale price of a foreclosed property is equal to the court's reference price. To compute the upper bound, instead, we must consider that the selling price of a foreclosed property can be up to 25 percent lower than the benchmark price set by the court.

${ }^{20}$ According to Astasy, the average discount was 55 percent in 2017 . However, they did not disclose the methodology behind their estimate, and we cannot compare their estimate with ours.

${ }^{21}$ Campbell et al. (2011) find that the foreclosure discount is 27 percent on average, while for Anenberg and Kung (2014) the estimate is 16 percent. Cohen et al. (2016) show that the estimates of the foreclosure discount in the US range between 0 and 28 percent.
} 
ing market. If this is the case, we should expect limited spillovers from foreclosures to the housing market. We investigate this hypothesis in the next section.

\section{The competitive effect of foreclosures}

In this section, we evaluate the impact of a foreclosed property's entry on the probability of observing price revisions for nearby non-foreclosed homes. In this way, we test if the presence of foreclosed homes affects home sellers' strategies in the housing market. The hypothesis is that foreclosures compete with other dwellings because their price is much lower than the market value. If this is the case, some home sellers may decide to revise downward their listing price. Therefore, we cannot consider the market for foreclosed homes isolated from the other segments of the housing market, notwithstanding the high foreclosure discount would point to a very limited arbitrage between housing market segments.

We implement the identification scheme proposed by Anenberg and Kung (2014). We test if a price revision is more likely to happen in the few weeks following the listing of a new nearby foreclosed home. This identification strategy relies on the assumption that the exact week in which a foreclosed home is listed is not correlated with any local shock that may cause sellers to adjust their list prices. This assumption is reasonable because strategic concerns do not motivate the timing of the entry of a foreclosed home into the market, which is the output of an administrative process and mostly determined by exogenous factors.

As noticed by Anenberg and Kung (2014), observing a price revision around the market entry of a foreclosed home is evidence that foreclosed properties compete with other listings. Therefore, the market for foreclosed houses would be linked to the other segments of the housing market.

Notice that this is only one possible channel through which foreclosures affect the housing market. In particular, foreclosures may negatively affect the local market to which they belong because of a disamenity effect. Foreclosures involve periods during which houses stand empty, and they lack maintenance expenditures. That may reduce the appeal of a neighborhood, and an increasing concentration of empty houses may eventually encourage crime. However, the effects of these disamenities should take place well before the listing of the foreclosed home, and it should start at the time of the foreclosure. If we observe an effect around the listing week, it is more plausible that competitive forces are at work.

We estimate how the probability of a price revision is affected by foreclosures entry using the following linear probability model:

$$
y_{i j, t}=\alpha_{j, t}+\beta \mathbf{X}_{i}+\delta_{1} N_{i, t-4}^{F}+\ldots+\delta_{9} N_{i, t+4}^{F}+\delta_{10} N_{i, t-4}^{O}+\ldots+\delta_{18} N_{i, t+4}^{O}+\varepsilon_{i j, t}
$$


where $y_{i j, t}$ it is an indicator variable equal to 1 if house $i$, belonging to microzone $j$, changes its listing price downward in week $t . N_{i, t-k}^{F}\left(N_{i, t-k}^{O}\right)$ is the logarithm of one plus the number of new foreclosures (other listings) entering into the market in week $t-k$ that are within a radius $r$ of listing $i .^{22}$ We consider both lags and leads to check that home sellers do not know in advance about the exact week of listing of a foreclosed home. As in Anenberg and Kung (2014) we consider the logs because in standard price competition models the competitive effect should be concave in the number of competitors. $\alpha_{j, t}$ is a set of week-by-microzone fixed effects. $\mathbf{X}$ is a vector of controls, which includes an indicator for whether the listing is a foreclosure, the number of days that the home has been on the market, the floor area of the house, and the type of property.

We estimate equation (3) over the full sample for three different values of the radius $r: 150,300$ and 450 meters. We report the most relevant parameters in Table 3 while the full results of the three specifications can be found in Table B.5 in Appendix B. We consider different specifications for the distance because there is ample evidence in the literature that the foreclosure impact is stronger for closer non-foreclosed homes. We want to test if the effect of foreclosures fades out over longer distances and then becomes no longer significant.

The effect of a new foreclosure listing in a radius of 150 meters is both statistically significant and economically relevant (Column 1). Considering both the parameters associated with $N_{i, t}^{F}$ and $N_{i, t-1}^{F}$, the additional probability of a price change caused by a new nearby foreclosure listing (relative to null) is 0.3 percent. $^{23}$ This is a sizeable effect because home sellers do not frequently adjust their asking price in Italy: the average probability of adjusting the list price is 1.4 percent. To give an idea of the relevance of this result, Anenberg and Kung (2014) finds that in San Francisco, the effect of new foreclosure listing on the propensity of home sellers to change their price is more than twice our estimate. However, we must compare this additional probability against a much higher baseline probability of price adjustment, which is about 7 percent in San Francisco.

The market entry of a non-foreclosure listing also has a statistically significant impact on the propensity to revise listing prices, although the additional probability of changing the price is less than 0.1 percent. ${ }^{24}$ We observe a smaller reaction than the listing of foreclosed properties plausibly because the latter enter the market with relatively low prices.

Columns 2 and 3 report the results of regression (3) when the radius $r$ is 300 and 450 meters, respectively. We find that spillovers from foreclosures are very local and dies out quite fast as the

\footnotetext{
${ }^{22}$ Since we take the log count of listings, we add one to avoid computing the logarithm of zero.

${ }^{23}$ This estimate can be retrieved by multiplying the parameters in Table 3 by $\log (2)$. Given the linear-log specification of the model, we are computing the effect of one new listing, $\log (2)$, compared to none, $\log (1)=0$.

${ }^{24}$ Other estimated parameters are statistically significant, but we do not comment on them because they are not economically meaningful.
} 
Table 3: Determinants of price changes

\begin{tabular}{lccc}
\hline \hline & \multicolumn{3}{c}{ Price change } \\
& $(1)$ & $(2)$ & $(3)$ \\
\hline New foreclosures t-1 & $0.0031^{* * *}$ & $0.0011^{* * *}$ & $0.0005^{* * *}$ \\
& $(0.0004)$ & $(0.0002)$ & $(0.0002)$ \\
New foreclosures t & $0.0019^{* * *}$ & $0.0008^{* * *}$ & $0.0005^{* *}$ \\
& $(0.0004)$ & $(0.0002)$ & $(0.0002)$ \\
New (no forecl.) listings t-1 & $0.0005^{* * *}$ & $0.0004^{* * *}$ & $0.0003^{* * *}$ \\
& $(0.0001)$ & $(0.0001)$ & $(0.0001)$ \\
New (no forecl.) listings t & 0.0001 & 0.0001 & 0.0000 \\
& $(0.0001)$ & $(0.0001)$ & $(0.0001)$ \\
Dummies & Microzone-week & Microzone-week & Microzone-week \\
Observations & $14,765,969$ & $14,765,969$ & $14,765,969$ \\
Adjusted $\mathrm{R}^{2}$ & 0.0029 & 0.0029 & 0.0029 \\
\hline
\end{tabular}

Notes: We report only the most relevant parameters (see Table B.5 for the other parameters). The dependent variable is an indicator variable taking value equal to 1 if the owner of house $i$ revises the listing price in week $t$. The number of new nearby listings that are within a radius $r$ of listing $i$ is measured in logs. We consider three different values for $r: 150$ meters (column 1), 300 meters (column 2), 450 meters (column 3). We control for the type of property, its size, its time on market up to week $t$ and a dummy variable that identify if it is a foreclosure listing. All changes are relative to a baseline probability of adjusting list price of 0.014 . *** Significant at the 1 percent level. ${ }^{* *}$ Significant at the 5 percent level. ${ }^{*}$ Significant at the 10 percent level. 
distance increases. The effect of foreclosures on the propensity to change the list price is more than halved at a distance of 300 meters and is very small when the radius is 450 meters.

\section{The effect of foreclosures on non-foreclosed house prices}

Since sellers react to the market entry of foreclosures, we cannot consider the market for foreclosed houses isolated from other segments of the real estate market, even if the spillovers are local. Consequently, it is essential to investigate to what extent the presence of foreclosures influences the prices of nearby non-foreclosed houses.

The estimation of this effect is a complex task because of the strong interrelationship between foreclosures and house prices. First, we discussed in section 4 that foreclosures are mainly in peripheral and suburban areas. Then, it is hard to say that they are random. Second, foreclosures are endogenous to house prices because a fall in house prices reduces dwellings' equity value. If the value of a house falls below that of the outstanding mortgage debt taken to buy it (negative equity), the homeowner has the incentive to strategically default on his debt. In principle, this is a mild issue in Italy because mortgage loans to households are recourse, but there is some concern about the behavior of companies. ${ }^{25}$ Third, there can be common shocks that may affect both house prices and foreclosures. A typical example is an income shock resulting from the shutdown of some relevant economic activity within the neighborhood. Some debtors may lose their jobs and no longer be able to pay their debts. Their homes would be foreclosed and sold through judicial auctions. At the same time, a lower income in the neighborhood would lead to lower demand for housing and thus lower house prices.

Mian et al. (2015) identify the causal impact of foreclosures on house prices using an instrumental variable approach. They find that the procedure to sell the collateral adopted in the different US States - judicial or nonjudicial foreclosures - affects the propensity of a house to be foreclosed but does not influence house prices except through foreclosures. As we cannot employ a similar identification strategy for the Italian case, we follow a variation of the approach proposed by Campbell et al. (2011) and Anenberg and Kung (2014).

To control for endogeneity, we compare the effects on the last asking price of a non-foreclosed home of nearby foreclosure listings before and after its delisting. Since we observe the full history of each listing, we know how many nearby foreclosures have been on the market in the weeks before

\footnotetext{
${ }^{25}$ The lender can go after other family assets if the value of the house is not enough to cover the debt. However, in practice, a significant share of the foreclosed dwellings may originate from companies' defaults, notably from construction firms. Companies continue to have the incentive to default if they have negative equity because of limited liability.
} 
and after the delisting of a house. To the extent that foreclosures negatively affect house prices, we expect that the coefficient associated with the number of foreclosure listings before the delisting to have a larger magnitude.

At the same time, to control for common economic shocks, we distinguish foreclosure listings in an inner circle with a radius of 150 meters and those in an outer ring with a distance in the interval 150-400 meters for each delisted house. The listings in the outer ring can be considered a control group. A common negative shock should generate the same downward trend in house prices over a 400 meters distance, absent any foreclosure. Moreover, since foreclosure spillovers are local, they should be stronger on the prices of houses that are closer. The results in the previous section indicate that this is a reasonable assumption, and they provide support for the choice of the radius. ${ }^{26}$

To interpret our results in terms of spillovers on sale prices, it must be the case that the listing of a foreclosed home: (i) does not affect the average discount applied to the listing prices of nearby homes, and (ii) does not change the probability that delisting of a nearby home corresponds to a sale instead of a withdrawal. The analysis in section 3.1 provides evidence that the first condition is satisfied. Moreover, the evidence that home sellers revise their listing price following the listing of a nearby foreclosed property further enhances the results in section 3.1.

Regarding the second condition, instead, the listing of a nearby foreclosed property could lead to a higher incidence of withdrawals. Therefore, listing prices would be a poor proxy for sale prices precisely where more foreclosed properties are listed. ${ }^{27}$ However, the opposite could also be true. Home sellers may want to speed up the sale of their house because they expect that the listings of foreclosed properties can induce a reduction in house prices. We do not have microdata to test if condition (ii) is satisfied. However, the fact there is no causal impact of foreclosures on the time-on-market - as we will show below - and there is no correlation of foreclosure listings with the average discount on listing prices is reassuring evidence.

We enrich regression (2) by including measures of nearby foreclosures as covariates. Let $N_{i, 150}^{F-}$ $\left(N_{i, 150}^{F+}\right)$ denote the log count of foreclosures listings within a 150 meters radius of dwelling $i$ during the 60 days before (after) the delisting of dwelling $i .{ }^{28} N_{i, 400}^{F-}$ and $N_{i, 400}^{F+}$ are similarly defined, but

\footnotetext{
${ }^{26}$ The distances taken into consideration here are very similar to those used in the literature for the US.

${ }^{27}$ The issue is that the listing prices of withdrawn properties can be systematically different from those of houses transacted. In particular, the listing prices of withdrawn houses are likely higher than those sold. For this reason, we would be underestimating the negative spillover of foreclosures on house prices.

${ }^{28}$ Also in this case, we add one to avoid computing the logarithm of zero.
} 
we consider listings between 150 and 400 meters. $^{29}$ We estimate the following regression:

$$
\begin{array}{r}
P_{i j t}=\alpha_{j t}+\beta \mathbf{X}_{i}+\delta_{150}^{-} N_{i, 150}^{F-}+\delta_{150}^{+} N_{i, 150}^{F+}+\delta_{i, 400}^{-} N_{i, 400}^{F-}+\delta_{i, 400}^{+} N_{i, 400}^{F+}+ \\
\gamma_{150}^{-} N_{i, 150}^{O-}+\gamma_{150}^{+} N_{i, 150}^{O+}+\gamma_{400}^{-} N_{i, 400}^{O-}+\gamma_{400}^{+} N_{i, 400}^{O+}+\varepsilon_{i j t}
\end{array}
$$

where $P_{i j t}$ is the logarithm of the last observed listing price for a non-foreclosed dwelling $i$, located in the microzone $j$ and delisted in month $t$. As in section 4 we control for house price variation over time at the microzone level and for the physical characteristics of houses $i$. Finally, we control for the log of the number of non foreclosure listings, as for foreclosures. That allows us to estimate if the effect of foreclosures is similar to the one of any other listing.

This specification is different from 3 because we are interested in the effect on house prices of a nearby foreclosure listing - i.e. the fact that is on the market for several weeks and compete with other houses - not just its market entry. ${ }^{30}$

We measure the spillover effect of foreclosures on nearby house prices as $\delta_{150}^{-}-\delta_{150}^{+}$, namely the difference between past and future foreclosure coefficients in the inner ring, controlling for past and future foreclosures within the outer ring. Similarly, we compute the spillover effect of other listings as $\gamma_{150}^{-}-\gamma_{150}^{+}$. We also estimate a more parsimonious version of $(4)$, in which we consider only the information about the past listings.

Table 4 reports our results. In Column 1, we show the estimates of the reduced model. Since we are considering a log-log model, the impact on the asking price of having one nearby foreclosure listing (relative to none) in the 60 days before delisting is -3.6 percent. ${ }^{31}$ The impact of having a non-foreclosure listing is still negative, but much smaller (-0.8 percent).

According to this specification, also foreclosures in the outer ring affect house prices. However, their spillovers (as measured by $\delta_{400}^{-}$) are much lower than those nearby. That is consistent with our identification strategy and with the estimates of the previous section.

We report the results of our full specification in Column 3. The impact of a foreclosure on house prices in the inner circle (relative to the outer ring) is -1.1 percent. This is an estimate consistent with those of Campbell et al. (2011) and Anenberg and Kung (2014) for the US. According to

\footnotetext{
${ }^{29}$ The choice to consider the logarithm of the number of foreclosures is motivated by the results of (Campbell et al., 2011). They find that the effect of nearby foreclosures is concave in the number of foreclosures.

${ }^{30}$ Our specification is very similar toCampbell et al. (2011) and Anenberg and Kung (2014). Differently from us, Campbell et al. (2011) consider a one-year time window for foreclosures before and after the sale of a house, and they do not control for the listing of non-foreclosed properties. Anenberg and Kung (2014) use sale prices as the dependent variable and consider a richer specification, where they control for the number of foreclosed and not-foreclosed properties in all their different stages of the listing process.

${ }^{31}$ The effect of an additional foreclosure listing relative to none is $e^{\delta_{150}^{-} *[\log (2)-\log (1)]}-1=\exp ^{\delta^{-} 0^{*} \log (2)}-1 \approx$ $\delta_{150}^{-} * \log (2)$
} 
Table 4: Local effects of foreclosures on house prices and time-on-market

\begin{tabular}{|c|c|c|c|c|}
\hline & $\begin{array}{l}\text { Listing price } \\
\text { (1) }\end{array}$ & $\begin{array}{c}\text { Time on market } \\
(2)\end{array}$ & $\begin{array}{l}\text { Listing price } \\
\text { (3) }\end{array}$ & $\begin{array}{c}\text { Time on market } \\
\text { (4) }\end{array}$ \\
\hline$\gamma_{400}^{-}$ & $\begin{array}{c}0.0057^{* * *} \\
(0.0012)\end{array}$ & $\begin{array}{l}-0.0029 \\
(0.0030)\end{array}$ & & \\
\hline$\delta_{400}^{-}$ & $\begin{array}{c}-0.0178^{* * *} \\
(0.0012)\end{array}$ & $\begin{array}{c}0.0060^{* *} \\
(0.0030)\end{array}$ & & \\
\hline$\gamma_{150}^{-}$ & $\begin{array}{c}-0.0114^{* * *} \\
(0.0010)\end{array}$ & $\begin{array}{c}0.0300^{* * *} \\
(0.0026)\end{array}$ & & \\
\hline$\delta_{150}^{-}$ & $\begin{array}{c}-0.0519^{* * *} \\
(0.0015)\end{array}$ & $\begin{array}{c}-0.0077^{* *} \\
(0.0039)\end{array}$ & & \\
\hline$\gamma_{400}^{-}-\gamma_{400}^{+}$ & & & $\begin{array}{l}-0.0002 \\
(0.0058)\end{array}$ & $\begin{array}{c}0.0091 \\
(0.0148)\end{array}$ \\
\hline$\delta_{400}^{-}-\delta_{400}^{+}$ & & & $\begin{array}{l}-0.0021 \\
(0.0035)\end{array}$ & $\begin{array}{l}-0.0070 \\
(0.0090)\end{array}$ \\
\hline$\gamma_{150}^{-}-\gamma_{150}^{+}$ & & & $\begin{array}{c}-0.0158^{* * *} \\
(0.0049)\end{array}$ & $\begin{array}{c}0.0436^{* * *} \\
(0.0126)\end{array}$ \\
\hline$\delta_{150}^{-}-\delta_{150}^{+}$ & & & $\begin{array}{c}-0.0162^{* * *} \\
(0.0047)\end{array}$ & $\begin{array}{c}0.0060 \\
(0.0119)\end{array}$ \\
\hline Dummies & Microzone-month & Microzone-month & Microzone-month & Microzone-month \\
\hline Observations & 407,167 & 407,177 & 407,167 & 407,177 \\
\hline Adjusted $\mathrm{R}^{2}$ & 0.5219 & 0.0137 & 0.5220 & 0.0137 \\
\hline
\end{tabular}

Notes: The dependent variables and the number of nearby listings are measured in logs. Parameters denoted by $\delta$ are associated with nearby foreclosures listings, while $\gamma$ refers to other listings. We control for the following home physical characteristics: property type (apartment or detached house), size (square meters), number of bathrooms, presence of a balcony, parking space/box, maintenance status and floor level. Time effects refer to the month in which a house is delisted. ${ }^{* * *}$ Significant at the 1 percent level. ${ }^{* *}$ Significant at the 5 percent level. ${ }^{*}$ Significant at the 10 percent level. 
Campbell et al. (2011), a foreclosure that takes place 0.05 miles away - that is about half the distance we consider in this study - lowers the price of a nearby house by about 1 percent. ${ }^{32}$ Instead, for Anenberg and Kung (2014) houses that are less than 0.1 miles from a foreclosure listing are sold at a 1.6 percent lower price. Also, the effect of foreclosures is the same as other listings, as in Anenberg and Kung (2014). The effect of listings in the outer circle is negative, although not statistically significant for both foreclosures and other listings.

To understand the implications of foreclosures for market liquidity, we considered an additional specification in which the dependent variable is the logarithm of the number of days the dwelling has been listed. Columns 2 and 4 report the results. The number of non-foreclosure listings has a significant impact on time-on-market. The presence of one listing in the inner circle (compared to none) implies that the time-on-market is higher by 3.2 percent. At the opposite foreclosures do not affect the time-on-market.

\section{Conclusion}

We investigate the impact of foreclosures on the Italian housing market. Despite a considerable foreclosure discount suggests that the market for foreclosures is isolated from other segments of the housing market, we find evidence of significant spillovers from foreclosures to the market of non-foreclosed homes.

Home sellers have a higher propensity to revise downward their asking price in the same week and the week following the market entry of a nearby foreclosure. This effect is local and decreasing in the distance from the foreclosed house.

Foreclosures compete in the housing market with non-foreclosure listings and affect the prices of nearby non-foreclosed houses. We find that the impact of foreclosures on nearby house prices is negative and significant.

In recent years, the number of foreclosures has been very high compared to the period preceding the global financial crisis compared with the total number of transactions in the housing market. Our econometric strategy does not quantify the effect of foreclosures on the aggregate trend of house prices in Italy. However, our results suggest that foreclosures are likely to be one of the factors that have dampened house prices in Italy in the last decade.

\footnotetext{
${ }^{32} \mathrm{~A}$ similar result has been found by (Hartley, 2014).
} 


\section{References}

Anenberg, Elliot and Edward Kung, "Estimates of the size and source of price declines due to nearby foreclosures," American Economic Review, 2014, 104 (8), 2527-51.

Bank of Italy, Annual Report 2018.

Calomiris, Charles W, Stanley D Longhofer, and William R Miles, "The foreclosurehouse price nexus: a panel VAR model for US states, 1981-2009," Real Estate Economics, 2013, $41(4), 709-746$.

Campbell, John Y, Stefano Giglio, and Parag Pathak, "Forced sales and house prices," American Economic Review, 2011, 101 (5), 2108-31.

Ciocchetta, Federica, Wanda Cornacchia, Roberto Felici, and Michele Loberto, "Assessing financial stability risks from the real estate market in Italy," Questioni di Economia e Finanza (Occasional Papers) 323, Bank of Italy, Economic Research and International Relations Area March 2016.

Cohen, Jeffrey P., Cletus C. Coughlin, and Vincent W. Yao, "Sales of Distressed Residential Property: What Have We Learned from Recent Research?," Federal Reserve Bank of St. Louis Review, 2016, 3, 159-88.

Fisher, Lynn M, Lauren Lambie-Hanson, and Paul Willen, "The role of proximity in foreclosure externalities: Evidence from condominiums," American Economic Journal: Economic Policy, 2015, 7 (1), 119-40.

Foote, Christopher L, Kristopher Gerardi, and Paul S Willen, "Negative equity and foreclosure: Theory and evidence," Journal of Urban Economics, 2008, 64 (2), 234-245.

Gerardi, Kristopher, Eric Rosenblatt, Paul S Willen, and Vincent Yao, "Foreclosure externalities: New evidence," Journal of Urban Economics, 2015, 87, 42-56.

Giacomelli, Silvia, Tommaso Orlando, and Giacomo Rodano, "Real estate foreclosures: the effects of the 2015-16 reforms on the length of the proceedings," Notes on Financial Stability and Supervision 16, Bank of Italy 2019.

Guren, Adam M and Timothy J McQuade, "How do foreclosures exacerbate housing downturns?," Technical Report, National Bureau of Economic Research 2019. 
Harding, John P, Eric Rosenblatt, and Vincent W Yao, "The contagion effect of foreclosed properties," Journal of Urban Economics, 2009, 66 (3), 164-178.

_ , _, and _ , "The foreclosure discount: Myth or reality?," Journal of Urban Economics, 2012, $71(2), 204-218$.

Hartley, Daniel, "The effect of foreclosures on nearby housing prices: Supply or dis-amenity?," Regional Science and Urban Economics, 2014, 49, 108-117.

Immergluck, Dan and Geoff Smith, "The external costs of foreclosure: The impact of singlefamily mortgage foreclosures on property values," Housing Policy Debate, 2006, 17 (1), 57-79.

Kennedy, Peter E., "Estimation with Correctly Interpreted Dummy Variables in Semilogarithmic Equations," The American Economic Review, 1981, 71 (4), 801-801.

Lambie-Hanson, Lauren, "When does delinquency result in neglect? Mortgage distress and property maintenance," Journal of Urban Economics, 2015, 90, 1-16.

Loberto, Michele, Andrea Luciani, and Marco Pangallo, "What do online listings tell us about the housing market?," 2020.

Mian, Atif, Amir Suf, and Francesco Trebbi, "Foreclosures, house prices, and the real economy," The Journal of Finance, 2015, 70 (6), 2587-2634.

Osservatorio del Mercato Immobiliare, Manuale della Banca Dati Quotazioni dell'Osservatorio del Mercato Immobiliare 2017.

Towe, Charles and Chad Lawley, "The contagion effect of neighboring foreclosures," American Economic Journal: Economic Policy, 2013, 5 (2), 313-35. 


\section{A Data}

Listings. The source data which we obtained from Immobiliare.it are contained in weekly files.

The information available for each ad is reported in Table A.1.

\begin{tabular}{|ll|}
\hline Type of data & Variables \\
\hline Numerical & Price, floor area, rooms, bathrooms \\
\hline Categorical & $\begin{array}{l}\text { Property type, furniture, kitchen type, heating type, maintenance status, } \\
\text { balcony, terrace, floor, air conditioning, energy class, basement, utility room }\end{array}$ \\
\hline Related to the building & Elevator, type of garden, garage, porter, building category \\
\hline Contractual & Foreclosure auction, contract type \\
\hline Related to the seller & $\begin{array}{l}\text { Publisher type (private citizen or real estate agency), agency name and ad- } \\
\text { dress }\end{array}$ \\
\hline Geographical & Longitude, latitude, address \\
\hline Temporal & Ad posted, ad removed, ad modified \\
\hline Textual & Description \\
\hline
\end{tabular}

Table A.1: Information contained in the database provided by Immobiliare.it. For a complete description of the meaning of the variables, see Loberto et al. (2020). If the variables in italic are missing, we perform semantic analysis on the textual description of the ads to recover the information.

House prices. OMI, a branch of the Italian Tax Office, disseminates estimates of the minimum and maximal house values in euros per square meter, $P_{l}$ and $P_{h}$, at a very granular level twice per year. House values are available for all types of properties (i.e. apartments or detached houses) and OMI microzones - which are uniform socio-economic areas - in the Italian cities. OMI design these microzones in order to have a set of homogeneous local housing markets. $P_{l}$ and $P_{h}$ are estimated based on a limited sample of house sales and valuations by real estate experts. Further information is available at https://www.agenziaentrate.gov.it/wps/content/Nsilib/Nsi/Schede/FabbricatiTerreni/omi.

For a microzone, multiple estimates for house prices can exist, one for each type of property prevalent in the microzone. Unfortunately, the classification of property types follows on the cadastral registry, which is not very precise. Moreover, we do not know the composition of the housing stock in each microzone, and therefore we cannot compute the correct weights to aggregate the different estimates.

We define the average house value in the OMI microzone $j$ as $\bar{P}_{j}=\frac{1}{2 N_{j}} \sum_{k=1}^{N_{j}}\left(P_{l k j}+P_{h k j}\right)$, where $N_{j}$ is the number of property types in microzone $j . P_{l k j}$ and $P_{h k j}$ are the minimum and maximum price, respectively, for each house typology.

We estimate the average house values at the city level as a simple average of the $\bar{P}_{j}$. For further aggregation, we compute weighted averages of the cities' average house values. We use as weights the stock of houses according to the 2011 Census. OMI estimates are not designed for statistical 
purposes, and the index we construct must not be considered equivalent to a quality-adjusted price index.

Istat disseminates quality-adjusted (hedonic) house price indexes. However, their indicators' reference area is not consistent with our listing data, apart from three city-level indexes referred to the main Italian cities: Rome, Milan and Turin.

Census data. We retrieve detailed information on the neighborhood's socio-economic characteristics and the stock of buildings in the surrounding area from the 2011 Census. Istat census tracts are much smaller than OMI micro-zones (indeed, there are approximately 400,000 Istat census tracts over the Italian territory compared to 27,000 OMI micro-zones) and do not necessarily coincide with them. We perform spatial matching of the polygons representing the tracts and the micro-zones and impute the Istat variables to the OMI micro-zones according to the overlap percentage of the polygons. For example, if an Istat census tract comprises 2,000 housing units and it straddles two OMI micro-zones, such that there is a $50 \%$ overlap for both, we impute 1,000 housing units to each of the two OMI micro-zones.

Italian Housing Market Survey. The Italian Housing Market Survey, conducted quarterly by Banca d'Italia, Tecnoborsa and OMI, covers about 1,200 real estate agents and describes their opinions regarding the current and expected course of house sales, price trends, rental prices and contracts. In this paper, we consider the survey results about the average discount on listing prices and the time-on-market.

The average discount is computed based on the answers to the following question: For the primary type of property sold in the reference quarter, compared with the seller's first asking price how was the selling price? Real estate agents must reports an interval for the discount (higher than $30 \%$, between $20 \%$ and $30 \%$, between $10 \%$ and $20 \%$, between $5 \%$ and $10 \%$, less than $5 \%$, selling price equal (or higher than) the asking price). The average discount is computed as the weighted average of the mean values in each interval.

The estimate of the time-on-market is based on the following question: Considering the total number of homes sold by you in the reference quarter, how many months passed on average between a house being registered with you and its sale (signature of preliminary contract)? Agents reply to this question by reporting the number of months. Then, the final statistics are computed by averaging the values reported by the agents.

Additional informations is available at https://www.bancaditalia.it/pubblicazioni/sondaggio-abitazioni/ index.html?com.dotmarketing.htmlpage.language $=1$.

Estimation of the discount on listing prices. We computed for each microzone $j$ and semester 
$t$ the ratio between the average listing price per s.m., $\bar{P}_{j t}^{l}$, and the average house prices per s.m. based on OMI data, $\bar{P}_{j t}$. The latter are estimated based on the procedure described above. Then, we compute the discount as $100\left(\frac{\bar{P}_{j t}^{l}}{\bar{P}_{j t}}-1\right)$.

There is a critical measurement issue. Since for many microzones OMI disseminates multiple estimates - one per each property typology -and we do not know the composition of the housing stock for each microzone, $\bar{P}_{j t}$ can be a biased estimate of the average house prices in microzone $j$. As a consequence, the average discount may be biased for some microzone, and in some cases even unreliable.

However, we find that the median of the distribution of the average discount across microzones $(12.7 \%)$ is consistent with the results of the Italian Housing Market Survey, where real estate agents provide an estimate based on the transaction they brokered (see Figures C.3). ${ }^{33}$ Moreover, the bias is constant over time, as the composition of the housing stock is almost fixed in the short period that we consider. Different property typologies show off minimal heterogeneity in the growth rates of their prices inside a microzone.

\footnotetext{
${ }^{33}$ The results of the survey on real estate agents refer to the whole country, not just to the cities in our sample.
} 


\section{B Additional tables}

Table B.1: Descriptive statistics about the local markets

\begin{tabular}{lcccccc}
\hline Variable & \multicolumn{5}{c}{ Percentile } & \multirow{2}{*}{ Mean } \\
\cline { 2 - 6 } & 5 & 25 & 50 & 75 & 95 & \\
\hline Population & 270.2 & 1604.5 & 4473.0 & 10592.2 & 27589.3 & 8049.8 \\
Households & 108.6 & 681.8 & 1874.5 & 4582.2 & 12226.4 & 3528.5 \\
Housing units & 152.6 & 896.5 & 2388.0 & 5527.2 & 13750.6 & 4166.2 \\
Share of owner-occupied & 47.2 & 63.1 & 70.2 & 75.8 & 82.5 & 68.3 \\
Average house value & 765.6 & 1170.0 & 1532.5 & 2121.7 & 3339.0 & 1757.1 \\
Average asking price & 878.4 & 1290.1 & 1784.4 & 2453.8 & 4025.1 & 2013.5 \\
\hline
\end{tabular}

Table B.2: Correlation between the number of listings and the housing stock in the local markets

\begin{tabular}{lccc}
\hline & Foreclosures & Other listings & Housing stock \\
\hline Foreclosures & 1.00 & & \\
Other listings & 0.70 & 1.00 & \\
Housing stock & 0.58 & 0.91 & 1.00 \\
\hline
\end{tabular}

Table B.3: Determinants of the discount on listing prices

\begin{tabular}{lc}
\hline \hline & \\
& Ratio between average listing and sale prices \\
\hline Foreclosures & -0.008 \\
& $(0.024)$ \\
Other listings & $0.023^{* * *}$ \\
& $(0.005)$ \\
Housing stock & $-0.001^{* * *}$ \\
& $(0.000)$ \\
Dummies & City + semester \\
Observations & 9,415 \\
Adjusted $\mathrm{R}^{2}$ & 0.270 \\
\hline
\end{tabular}

Notes: The dependent variable is the ratio (multiplied by 100) between the average listing and sale prices in the local market $i$ during the semester $t$. The regressors are the number of listings at time $t$. We control for the housing stock, the location inside the city, and we add city and time dummies. ${ }^{* * *}$ Significant at the 1 percent level. ${ }^{* *}$ Significant at the 5 percent level. ${ }^{*}$ Significant at the 10 percent level. 
Table B.5: Determinants of price changes

\begin{tabular}{|c|c|c|c|}
\hline & \multicolumn{3}{|c|}{ Price change } \\
\hline & $(1)$ & $(2)$ & $(3)$ \\
\hline \multirow[t]{2}{*}{ New foreclosures $t-4$} & $-0.0009^{* *}$ & -0.0001 & 0.0001 \\
\hline & $(0.0004)$ & $(0.0002)$ & $(0.0002)$ \\
\hline \multirow[t]{2}{*}{ New foreclosures $t-3$} & -0.0004 & -0.0001 & -0.0002 \\
\hline & $(0.0004)$ & $(0.0002)$ & $(0.0002)$ \\
\hline \multirow[t]{2}{*}{ New foreclosures $t-2$} & -0.0001 & -0.0001 & 0.0002 \\
\hline & $(0.0004)$ & $(0.0002)$ & $(0.0002)$ \\
\hline \multirow[t]{2}{*}{ New foreclosures $t-1$} & $0.0031^{* * *}$ & $0.0011^{* * *}$ & $0.0005^{* * *}$ \\
\hline & $(0.0004)$ & $(0.0002)$ & $(0.0002)$ \\
\hline \multirow[t]{2}{*}{ New foreclosures $t$} & $0.0019^{* * *}$ & $0.0008^{* * *}$ & $0.0005^{* *}$ \\
\hline & $(0.0004)$ & $(0.0002)$ & $(0.0002)$ \\
\hline \multirow[t]{2}{*}{ New foreclosures $t+1$} & -0.0001 & 0.0001 & -0.0001 \\
\hline & $(0.0004)$ & $(0.0002)$ & $(0.0002)$ \\
\hline \multirow[t]{2}{*}{ New foreclosures $t+2$} & 0.0000 & -0.0001 & -0.0002 \\
\hline & $(0.0004)$ & $(0.0002)$ & $(0.0002)$ \\
\hline \multirow[t]{2}{*}{ New foreclosures $t+3$} & -0.0004 & -0.0001 & -0.0000 \\
\hline & $(0.0004)$ & $(0.0002)$ & $(0.0002)$ \\
\hline \multirow[t]{2}{*}{ New foreclosures $t+4$} & 0.0006 & $0.0007^{* * *}$ & $0.0004^{* *}$ \\
\hline & $(0.0004)$ & $(0.0002)$ & $(0.0002)$ \\
\hline \multirow[t]{2}{*}{ New (no forecl.) listings t- 4} & -0.0000 & 0.0000 & 0.0001 \\
\hline & $(0.0001)$ & $(0.0001)$ & $(0.0001)$ \\
\hline \multirow[t]{2}{*}{ New (no forecl.) listings t-3 } & $-0.0002^{*}$ & -0.0000 & -0.0001 \\
\hline & $(0.0001)$ & $(0.0001)$ & $(0.0001)$ \\
\hline \multirow[t]{2}{*}{ New (no forecl.) listings t-2 } & -0.0001 & -0.0001 & 0.0001 \\
\hline & $(0.0001)$ & $(0.0001)$ & $(0.0001)$ \\
\hline \multirow[t]{2}{*}{ New (no forecl.) listings t-1 } & $0.0005^{* * *}$ & $0.0004^{* * *}$ & $0.0003^{* * *}$ \\
\hline & $(0.0001)$ & $(0.0001)$ & $(0.0001)$ \\
\hline \multirow[t]{2}{*}{ New (no forecl.) listings $t$} & 0.0001 & 0.0001 & 0.0000 \\
\hline & $(0.0001)$ & $(0.0001)$ & $(0.0001)$ \\
\hline \multirow[t]{2}{*}{ New (no forecl.) listings $t+1$} & -0.0001 & 0.0000 & 0.0001 \\
\hline & $(0.0001)$ & $(0.0001)$ & $(0.0001)$ \\
\hline \multirow[t]{2}{*}{ New (no forecl.) listings $t+2$} & $-0.0003^{* *}$ & -0.0001 & 0.0000 \\
\hline & $(0.0001)$ & $(0.0001)$ & $(0.0001)$ \\
\hline \multirow[t]{2}{*}{ New (no forecl.) listings $t+3$} & 0.0001 & $0.0003^{* * *}$ & $0.0002^{* *}$ \\
\hline & $(0.0001)$ & $(0.0001)$ & $(0.0001)$ \\
\hline \multirow[t]{2}{*}{ New (no forecl.) listings $t+4$} & $-0.0005^{* * *}$ & $-0.0002^{*}$ & $-0.0002^{* *}$ \\
\hline & $(0.0001)$ & $(0.0001)$ & $(0.0001)$ \\
\hline Dummies & Microzone-week & Microzone-week & Microzone-week \\
\hline Observations & $12,342,092$ & $12,342,092$ & $12,342,092$ \\
\hline Adjusted $\mathrm{R}^{2}$ & 0.0028 & 0.0028 & 0.0028 \\
\hline
\end{tabular}

Notes: The dependent variable is an indicator variable taking value equal to 1 if the owner of house $i$ revises the listing price in week $t$. The number of new nearby listings that are within a radius $r$ of listing $i$ is measured in logs. We consider three different values for $r$ : 150 meters (column 1), 300 meters (column 2), 450 meters (column 3). We control for the type of property, its size, its time on market up to week $t$ and a dummy variable that identify if it is a foreclosure listing. All changes are relative to a baseline probability of adjusting list price of 0.014 . ${ }^{* * *}$ Significant at the 1 percent level. ${ }^{* *}$ Significant at the 5 percent level. *Significant at the 10 percent level. 
Table B.4: Time-on-market and average discount to listing prices

\begin{tabular}{lc}
\hline \hline & \\
& Ratio between average listing and sale prices \\
\hline Time-on-market & $0.020^{* *}$ \\
& $(0.010)$ \\
Housing stock & $-0.000^{* * *}$ \\
& $(0.000)$ \\
Observations & 1,880 \\
Adjusted $\mathrm{R}^{2}$ & 0.307 \\
\hline
\end{tabular}

Notes: The dependent variable is the ratio (multiplied by 100) between the average listing and sale prices in the local market $i$ in the whole period. The time-on-market is measured in days. We control for the housing stock, the location inside the city, and we add city dummies. ${ }^{* * *}$ Significant at the 1 percent level. ${ }^{* *}$ Significant at the 5 percent level. * Significant at the 10 percent level.

\section{Figures}

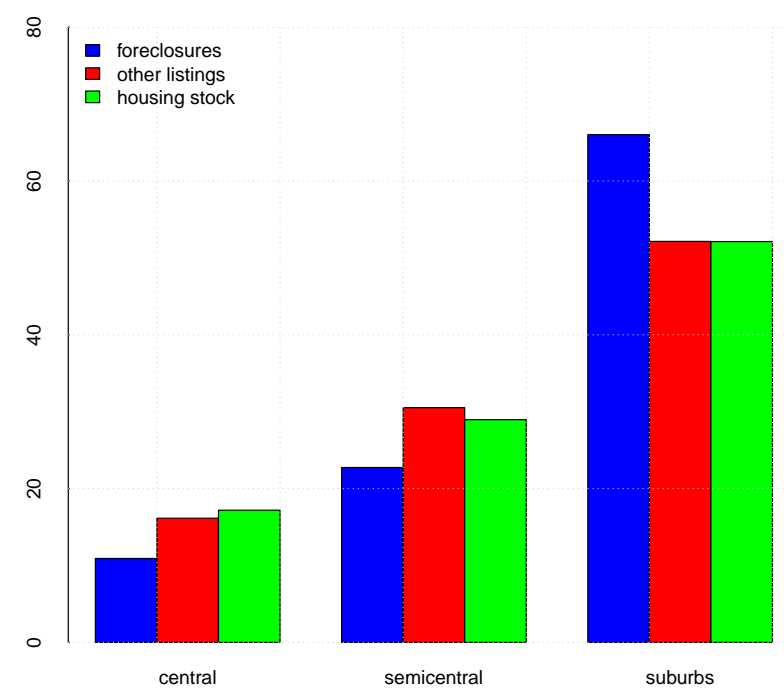

Figure C.1: Distribution of foreclosed homes, other listings and housing stock inside by location (based on OMI classification). Percentage points. We merged the categories "suburbs" and "out-of-town". 


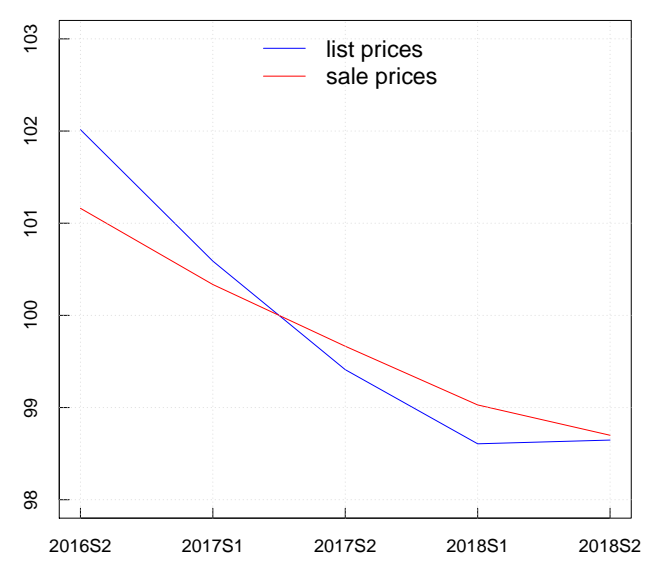

(a) All cities

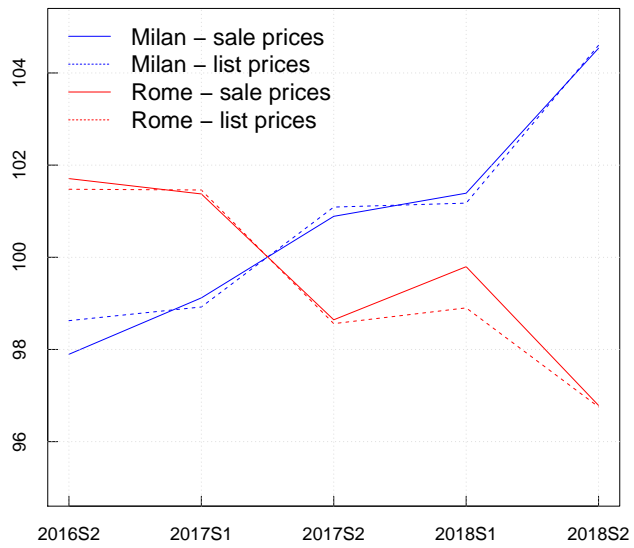

(b) Main cities

Figure C.2: Listing prices and sale prices. Indices 2017=100. Figure (a) reports aggregate indices for listing prices (Immobiliare.it) and sale prices (OMI) in all cities in our sample. Figure (b) reports listing and sale prices in the two main cities (Rome and Milan).

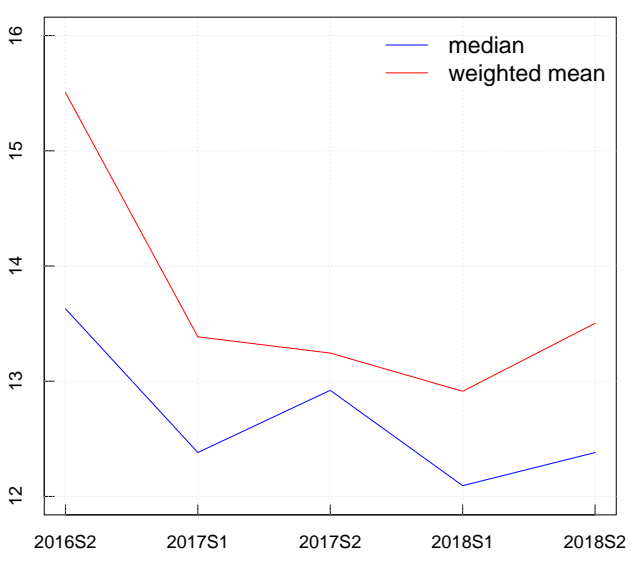

(a) Discount

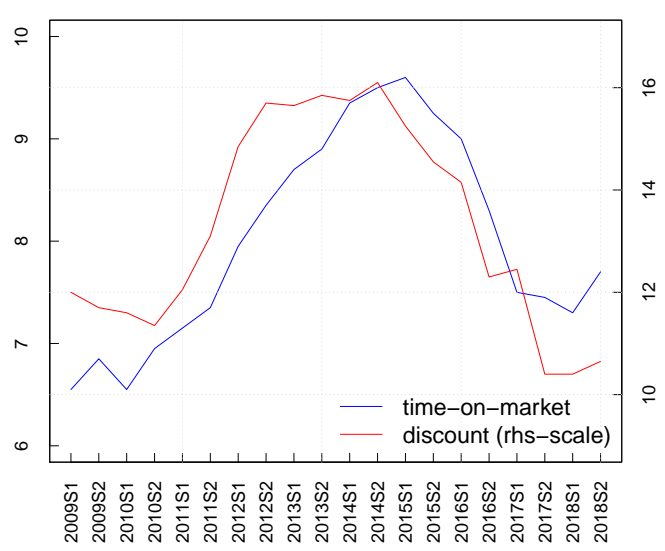

(b) Discount and time-on-market

Figure C.3: Discount applied to listing prices and time-on-market. Figure (a) reports the median and the weighted (using housing stocks) average for the discount across OMI microzones (measured in percentage points). The discount is computed as the ratio between the average listing price per s.m. and the average sale price per s.m. minus 1. Figure (b) reports the average discount (percentage points) and time-on market (months) in Italy according to the survey on real estate agents. 


\section{RECENTLY PUBLISHED “TEMI” (*)}

N.1301 - A quantitative analysis of distortions in managerial forecasts, by Yueran Ma, Tiziano Ropele, David Sraer and David Thesmar (November 2020).

N.1302 - Bargaining power and the Phillips curve: a micro-macro analysis, by Marco J. Lombardi, Marianna Riggi and Eliana Viviano (November 2020).

N. 1303 - The effects of structural reforms: Evidence from Italy, by Emanuela Ciapanna, Sauro Mocetti and Alessandro Notarpietro (November 2020).

N. 1304 - Consumption and Wealth: New Evidence from Italy, by Riccardo De Bonis, Danilo Liberati, John Muellbauer and Concetta Rondinelli (November 2020).

N. 1305 - Do details matter? An analysis of the Italian personal income tax, by Martino Tasso (November 2020).

N.1306 - Effects of eligibility for central bank purchases on corporate bond spreads, by Taneli Mäkinen, Fan Li, Andrea Mercatanti and Andrea Silvestrini (November 2020).

N. 1307 - On the design of grant assignment rules, by Francesca Modena, Santiago Pereda Fernandez and Giulia Martina Tanzi (December 2020).

N. 1308 - Monetary policy strategies in the New Normal: a model-based analysis for the euro area, by Fabio Busetti, Stefano Neri, Alessandro Notarpietro and Massimiliano Pisani (December 2020).

N.1309 - Rare disasters, the natural interest rate and monetary policy, by Alessandro Cantelmo (December 2020).

N.1310 - The market stabilization role of central bank asset purchases: high-frequency evidence from the COVID-19 crisis, by Marco Bernardini and Annalisa De Nicola (December 2020).

N. 1311 - Equity tail risk in the treasury bond market, by Dario Ruzzi and Mirco Rubin (December 2020).

N. 1312 - Scars of youth non-employment and labour market conditions, by Giulia Martina Tanzi (December 2020).

N. 1313 - The COVID-19 shock and a fiscal-monetary policy mix in a monetary union, by Anna Bartocci, Alessandro Notarpietro and Massimiliano Pisani (December 2020).

N.1314 - Working horizon and labour supply: the effect of raising the full retirement age on middle-aged individuals, by Francesca Carta and Marta De Philippis (February 2021).

N. 1315 - Bank credit and market-based finance for corporations: the effects of minibond issuances, by Steven Ongena, Sara Pinoli, Paola Rossi and Alessandro Scopelliti (February 2021).

N. 1316 - Is inflation targeting a strategy past its sell-by date?, by Alberto Locarno and Alessandra Locarno (February 2021).

N.1317 - Declining natural interest rate in the US: the pension system matters, by Jacopo Bonchi and Giacomo Caracciolo (February 2021).

N. 1318 - Can we measure inflation expectations using Twitter?, by Cristina Angelico, Juri Marcucci, Marcello Miccoli and Filippo Quarta (February 2021).

N. 1319 - Identifying deposits'outflows in real-time, by Edoardo Rainone (February 2021).

N.1320 - Whatever it takes to save the planet? Central banks and unconventional green policy, by Alessandro Ferrari and Valerio Nispi Landi (February 2021).

(*) Requests for copies should be sent to:

Banca d'Italia - Servizio Studi di struttura economica e finanziaria - Divisione Biblioteca e Archivio storico - Via Nazionale, 91 - 00184 Rome - (fax 003906 47922059). They are available on the Internet www.bancaditalia.it. 
ALBANESE G., M. CIOFFI and P. TOMMASINO, Legislators' behaviour and electoral rules: evidence from an Italian reform, European Journal of Political Economy, v. 59, pp. 423-444, WP 1135 (September 2017).

Aprigliano V., G. ARDizzI and L. MONTEFORTE, Using the payment system data to forecast the economic activity, International Journal of Central Banking, v. 15, 4, pp. 55-80, WP 1098 (February 2017).

ARnAudo D., G. MiCUCCI, M. RIGON and P. Rossi, Should I stay or should I go? Firms' mobility across banks in the aftermath of the financial crisis, Italian Economic Journal / Rivista italiana degli economisti, v. 5, 1, pp. 17-37, WP 1086 (October 2016).

BASSO G., F. D'AMURI and G. PERI, Immigrants, labor market dynamics and adjustment to shocks in the euro area, IMF Economic Review, v. 67, 3, pp. 528-572, WP 1195 (November 2018).

BAtini N., G. MELINA and S. VILla, Fiscal buffers, private debt, and recession: the good, the bad and the ugly, Journal of Macroeconomics, v. 62, WP 1186 (July 2018).

Burlon L., A. NotARPIETRO and M. PISANI, Macroeconomic effects of an open-ended asset purchase programme, Journal of Policy Modeling, v. 41, 6, pp. 1144-1159, WP 1185 (July 2018).

BUSETTI F. and M. CAIVANO, Low frequency drivers of the real interest rate: empirical evidence for advanced economies, International Finance, v. 22, 2, pp. 171-185, WP 1132 (September 2017).

CAPpelletti G., G. GuAZZAROtTI and P. TOMmasino, Tax deferral and mutual fund inflows: evidence from a quasi-natural experiment, Fiscal Studies, v. 40, 2, pp. 211-237, WP 938 (November 2013).

CARDANi R., A. PACCAGNINI and S. VILLA, Forecasting with instabilities: an application to DSGE models with financial frictions, Journal of Macroeconomics, v. 61, WP 1234 (September 2019).

Chiades P., L. Greco, V. Mengotto, L. Moretti and P. VAlbonesi, Fiscal consolidation by intergovernmental transfers cuts? The unpleasant effect on expenditure arrears, Economic Modelling, v. 77, pp. 266-275, WP 1076 (July 2016).

CIANI E., F. DAVID and G. DE BLASIO, Local responses to labor demand shocks: a re-assessment of the case of Italy, Regional Science and Urban Economics, v. 75, pp. 1-21, WP 1112 (April 2017).

CIANI E. and P. FISHER, Dif-in-dif estimators of multiplicative treatment effects, Journal of Econometric Methods, v. 8. 1, pp. 1-10, WP 985 (November 2014).

CIAPANNA E. and M. TABOGA, Bayesian analysis of coefficient instability in dynamic regressions, Econometrics, MDPI, Open Access Journal, v. 7, 3, pp.1-32, WP 836 (November 2011).

Coletta M., R. De Bonis and S. Piermattei, Household debt in OECD countries: the role of supply-side and demand-side factors, Social Indicators Research, v. 143, 3, pp. 1185-1217, WP 989 (November 2014).

Cova P., P. PAgAno and M. PISANI, Domestic and international effects of the Eurosystem Expanded Asset Purchase Programme, IMF Economic Review, v. 67, 2, pp. 315-348, WP 1036 (October 2015).

ERCOLANI V. and J. VALLE E AZEVEDO, How can the government spending multiplier be small at the zero lower bound?, Macroeconomic Dynamics, v. 23, 8. pp. 3457-2482, WP 1174 (April 2018).

FERrERo G., M. GROSS and S. NERI, On secular stagnation and low interest rates: demography matters, International Finance, v. 22, 3, pp. 262-278, WP 1137 (September 2017).

FoA G., L. GAmBACORTA, L. Guiso and P. E. Mistrulli, The supply side of household finance, Review of Financial Studies, v.32, 10, pp. 3762-3798, WP 1044 (November 2015).

GerAli A. and S. NERI, Natural rates across the Atlantic, Journal of Macroeconomics, v. 62, article 103019, WP 1140 (September 2017).

GIORDANO C., M. MARINUCCI and A. SILVESTRINI, The macro determinants of firms' and households' investment: evidence from Italy, Economic Modelling, v. 78, pp. 118-133, WP 1167 (March 2018).

GOMEllini M., D. PELlEGRINO and F. GIFFONI, Human capital and urban growth in Italy, 1981-2001, Review of Urban \& Regional Development Studies, v. 31, 2, pp. 77-101, WP 1127 (July 2017).

LiBERATI D. and M. LOBERTO, Taxation and housing markets with search frictions, Journal of Housing Economics, v. 46, article 101632, WP 1105 (March 2017).

MAGRI S., Are lenders using risk-based pricing in the Italian consumer loan market? The effect of the 2008 crisis, Journal of Credit Risk, v. 15, 1, pp. 27-65, WP 1164 (January 2018).

Mercatanti A., T. MAKINEN and A. SiLVESTRINI, The role of financial factors for european corporate investment, Journal of International Money and Finance, v. 96, pp. 246-258, WP 1148 (October 2017). 
Miglietta A., C. Picillo and M. PIETRUnTI, The impact of margin policies on the Italian repo market, The North American Journal of Economics and Finance, v. 50, WP 1028 (October 2015).

MONTEFORTE L. and V. RAPONI, Short-term forecasts of economic activity: are fortnightly factors useful?, Journal of Forecasting, v. 38, 3, pp. 207-221, WP 1177 (June 2018).

Neri S. and A. NotArpietro, Collateral constraints, the zero lower bound, and the debt-deflation mechanism, Economics Letters, v. 174, pp. 144-148, WP 1040 (November 2015).

PANCRAZI R. and M. PIETRUNTI, Natural expectations and home equity extraction, Journal of Housing Economics, v. 46, 4, WP 984 (November 2014).

Pereda FERnANDEZ S., Teachers and cheaters. Just an anagram?, Journal of Human Capital, v. 13, 4, pp. 635-669, WP 1047 (January 2016).

RigGi M., Capital destruction, jobless recoveries, and the discipline device role of unemployment, Macroeconomic Dynamics, v. 23, 2, pp. 590-624, WP 871 (July 2012).

AlessANDRi P. and M. BOTTERO, Bank lending in uncertain times, R European Economic Review, V. 128, WP 1109 (April 2017).

Antunes A. and V. ERCOlAnI, Public debt expansions and the dynamics of the household borrowing constraint, Review of Economic Dynamics, v. 37, pp. 1-32, WP 1268 (March 2020).

ARDUINI T., E. PATACCHINI and E. RAINONE, Treatment effects with heterogeneous externalities, Journal of Business \& Economic Statistics, , v. 38, 4, pp. 826-838, WP 974 (October 2014).

Bottero M., F. MeZZANOTTI and S. LENZU, Sovereign debt exposure and the Bank Lending Channel: impact on credit supply and the real economy, Journal of International Economics, v. 126, article 103328, WP 1032 (October 2015).

BRIPI F., D. LOSCHIAVO and D. REVELLI, Services trade and credit frictions: evidence with matched bankfirm data, The World Economy, v. 43, 5, pp. 1216-1252, WP 1110 (April 2017).

BRONZINI R., G. CARAMELLINO and S. MAGRI, Venture capitalists at work: a Diff-in-Diff approach at latestages of the screening process, Journal of Business Venturing, v. 35, 3, WP 1131 (September 2017).

BronzINI R., S. MocetTI and M. MONGARDINI, The economic effects of big events: evidence from the Great Jubilee 2000 in Rome, Journal of Regional Science, v. 60, 4, pp. 801-822, WP 1208 (February 2019).

COIBION O., Y. GORODNICHENKO and T. ROPELE, Inflation expectations and firms' decisions: new causal evidence, Quarterly Journal of Economics, v. 135, 1, pp. 165-219, WP 1219 (April 2019).

CORSELlO F. and V. NiSPI LANDI, Labor market and financial shocks: a time-varying analysis, Journal of Money, Credit and Banking, v. 52, 4, pp. 777-801, WP 1179 (June 2018).

COVA P. and F. NATOLI, The risk-taking channel of international financial flows, Journal of International Money and Finance, v. 102, WP 1152 (December 2017).

D'Alessio G., Measurement errors in survey data and the estimation of poverty and inequality indices, Statistica Applicata - Italian Journal of Applied Statistics, v. 32, 3, WP 1116 (June 2017).

Del Prete S. and S. FEDERICO, Do links between banks matter for bilateral trade? Evidence from financial crises, Review of World Economic, v. 156, 4, pp. 859 - 885, WP 1217 (April 2019).

D'IGNAZIO A. and C. MENON, The causal effect of credit Guarantees for SMEs: evidence from Italy, The Scandinavian Journal of Economics, v. 122, 1, pp. 191-218, WP 900 (February 2013).

ERCOLANI V. and F. NATOLI, Forecasting US recessions: the role of economic uncertainty, Economics Letters, v. 193, WP 1299 (October 2020).

MAKINEN T., L. SARNO and G. ZINNA, Risky bank guarantees, Journal of Financial Economics, v. 136, 2, pp. 490522, WP 1232 (July 2019).

MOdEnA F., E. RETTORE and G. M. TANZI, The effect of grants on university dropout rates: evidence from the Italian case, Journal of Human Capital, v. 14, 3, pp. 343-370, WP 1193 (September 2018).

NiSPI LANDI V., Capital controls spillovers, Journal of International Money and Finance, v. 109, WP 1184 (July 2018).

PERICOLI M., On risk factors of the stock-bond correlation, International Finance, v. 23, 3, pp. 392-416, WP 1198 (November 2018). 
RAINONE E., The network nature of OTC interest rates, Journal of Financial Markets, v.47, article 100525, WP 1022 (July 2015).

RAINONE E. and F. VACIRCA, Estimating the money market microstructure with negative and zero interest rates, Quantitative Finance, v. 20, 2, pp. 207-234, WP 1059 (March 2016).

RIZZICA L., Raising aspirations and higher education. Evidence from the UK's widening participation policy, Journal of Labor Economics, v. 38, 1, pp. 183-214, WP 1188 (September 2018).

SANTIONI, R., F. SCHIANTARELLI and P. STRAHAN, Internal capital markets in times of crisis: the benefit of group affiliation, Review of Finance, v. 24, 4, pp. 773-811, WP 1146 (October 2017).

SChiantarelli F., M. Stacchini and P. Strahan, Bank Quality, judicial efficiency and loan repayment delays in Italy, Journal of Finance, v. 75, 4, pp. 2139-2178, WP 1072 (July 2016).

\section{FORTHCOMING}

Accetturo A., A. LAmorgese, S. Mocetti and D. Pellegrino, Housing Price elasticity and growth: evidence from Italian cities, Journal of Economic Geography, WP 1267 (March 2020).

AlBAnese G., E. CIANI and G. DE BLASIO, Anything new in town? The local effects of urban regeneration policies in Italy, Regional Science and Urban Economics, WP 1214 (April 2019).

Albanese G., G. DE BlAsio and A. LOCATELLI, Does EU regional policy promote local TFP growth? Evidence from the Italian Mezzogiorno, Papers in Regional Science, WP 1253 (December 2019).

ANZUINI A. and L. Rossi, Fiscal policy in the US: a new measure of uncertainty and its effects on the American economy, Empirical Economics, WP 1197 (November 2018).

Bologna P., A. Miglietta and A. Segura, Contagion in the CoCos market? A case study of two stress events, International Journal of Central Banking, WP 1201 (November 2018).

Cova P., P. PAgAnO, A. NotARPIETRO and M. PisAni, Secular stagnation, R\&D, public investment and monetary policy: a global-model perspective, Macroeconomic Dynamics, WP 1156 (December 2017).

DE PHILIPPIS M., Multitask agents and incentives: the case of teaching and research for university professors, Economic Journal, WP 1156 (December 2015).

Del Prete S. and M. L. SteFAni, Women as "Gold Dust": gender diversity in top boards and the performance of Italian banks, Economic Notes, Monte dei Paschi di Siena, WP 1014 (June 2015).

Fidora M., C. GIORDANO and M. SchMitz, Real exchange rate misalignments in the Euro Area, Open Economies Review, WP 1042 (January 2018).

HERTWECK M., V. LEWIS and S. VILLA, Going the extra mile: effort by workers and job-seekers, Journal of Money, Credit and Banking, WP 1277 (June 2020).

Li F., A. MercatAnti, T. MAKINEN and A. SilveSTRINI, A regression discontinuity design for ordinal running variables: evaluating central bank purchases of corporate bonds, Annals of Applied Statistics, WP 1213 (March 2019).

LOSCHIAVO D., Household debt and income inequality: evidence from Italian survey data, Review of Income and Wealth, WP 1095 (January 2017).

METELli L. and F. NATOLI, The international transmission of US tax shocks: a proxy-SVAR approach, IMF Economic Review, WP 1223 (June 2019).

Mocetti S., G. RomA and E. RuBOLINO, Knocking on parents' doors: regulation and intergenerational mobility, Journal of Human Resources, WP 1182 (July 2018).

NisPi LANDI V. and A. SCHIAVONE, The effectiveness of capital controls, Open Economies Review, WP 1200 (November 2018).

PeReda Fernandez S., Copula-based random effects models for clustered data, Journal of Business \& Economic Statistics, WP 1092 (January 2017).

PERICOLI M. and M. TABOGA, Nearly exact Bayesian estimation of non-linear no-arbitrage term-structure models, Journal of Financial Econometrics, WP 1189 (September 2018). 